\title{
A rendszeres alkoholfogyasztás és a dohányzás hatása a vérnyomásra és a vérnyomáscélértékek elérési arányára kezelt hypertoniás betegekben
}

\author{
Kékes Ede dr. ${ }^{1,4}$ - Paksy András dr. ${ }^{2}$ - Baracsi-Botos Viktória dr. ${ }^{3,4}$ \\ Szőke Vince Bertalan dr. ${ }^{3,4}$. Járai Zoltán dr. ${ }^{3,4}$ \\ ${ }^{1}$ Pécsi Tudományegyetem, Általános Orvostudományi Kar, Klinikai Központ, \\ I. Belgyógyászati Klinika, Kardiológiai és Angiológiai Tanszék, Pécs \\ ${ }^{2}$ Aesculap Akadémia, Doktorjelöltek Iskolája, Budapest \\ ${ }^{3}$ Szent Imre Egyetemi Oktatókórház, Általános Kardiológiai Profil, Budapest \\ ${ }^{4}$ Magyar Hypertonia Társaság, Budapest
}

\begin{abstract}
Bevezetés: Az alkohol és a dohányzás vérnyomásra gyakorolt együttes hatásáról hypertoniás betegekben még hiányosak az ismereteink, bár tudjuk, hogy mindkettő cardiovascularis kockázati tényező.

Célkitüzés: Vizsgálatunk célja, hogy középkorú hypertoniás betegekben összehasonlítsuk a nem dohányzó és alkoholt rendszeresen nem fogyasztók vérnyomásértékeit, a célvérnyomást elérôk arányát és a szívfrekvenciát azokéval, akik rendszeresen dohányoznak és alkoholt fogyasztanak.

Módszer: A Magyar Hypertonia Regiszter adatbázisából 12 615, 45-64 éves beteg (6341 férfi és 6274 nő) került a jelenlegi elemzésbe, akiknél önbevallás alapján regisztráltuk a dohányzás és az alkoholfogyasztás mértékét.

Eredmények: Az átlagéletkor 55,8 $\pm 5,7$ év (férfiak) és 56,1 $\pm 5,5$ év (nők) volt. A férfiak 40,8\%-a, a nők 27,2\%-a rendszeresen dohányzott. A rendszeres alkoholfogyasztók aránya férfiaknál 38,1\%, nóknél 12,5\% volt. A nők esetében minden csoportban nagyobb $(\mathrm{p}<0,001)$ volt a célvérnyomást elérók aránya, mint a férfiaknál. A rendszeresen dohányzó és alkoholt fogyasztó betegek esetében kisebb volt a célvérnyomást elérők aránya, mint akik nem fogyasztanak rendszeresen alkoholt, és nem dohányoznak: a férfiak esetében $31,1 \%$ a 46,6\%-kal szemben ( $\mathrm{p}<0,001)$, nők esetében $41,1 \%$ a 49,8\%-kal szemben ( $\mathrm{p}<0,01)$. A szívfrekvencia átlaga nagyobb a csak dohányzók vagy rendszeres alkoholfogyasztók esetében.

Következtetés: A rendszeres alkoholfogyasztás és a dohányzás rontja a célvérnyomás elérésének esélyét középkorú, kezelt hypertoniás személyekben.
\end{abstract}

Orv Hetil. 2020; 161(30): 1252-1259.

Kulcsszavak: alkoholfogyasztás, dohányzás, vérnyomás, szívfrekvencia, hypertonia

The combined effect of regular alcohol consumption and smoking on blood pressure and on the achievement of blood pressure target values in treated hypertensive patients

Introduction: The combined effect of alcohol consumption and smoking on hypertension in hypertensive patients is still not completely clear, although both are known to be cardiovascular risk factors.

Aim: The aim of our study was to compare the blood pressure, the achievement of target blood pressure and heart rate of non-smokers and non-drinkers in the middle-aged hypertensive patients with those who smoke and drink regularly.

Method: From the database of the Hungarian Hypertension Registry, 12615 patients (6341 men and 6274 women) aged 45-64 years were included in the current analysis, who self-reported smoking habit and alcohol consumption. Results: The mean age of the patients was $55.8 \pm 5.7$ years (males) and $56.1 \pm 5.5$ years (females). The percentage of regular smokers was $40.8 \%$ and $27.2 \%$ among men and women, respectively. $38.1 \%$ of males and $12.5 \%$ of females were regular alcohol drinkers. The ratio of patients reaching goal blood pressure values was higher in all investigated 
groups of females than males $(\mathrm{p}<0.001)$. Regular smokers and drinkers have lower percentage of reaching goal blood pressure values: $31.1 \%$ versus $46.6 \%$ in males $(\mathrm{p}<0.001)$ and $41.1 \%$ versus $49.8 \%$ in females $(\mathrm{p}<0.01)$, respectively. The average of pulse rate was higher in patients who are smokers and regular drinkers.

Conclusion: Regular alcohol consumption and smoking decrease the chance of reaching blood pressure goal values in middle-aged, treated hypertensive patients.

Keywords: alcohol consumption, smoking, blood pressure, heart rate, hypertension

Kékes E, Paksy A, Baracsi-Botos V, Szőke VB, Járai Z. [The combined effect of regular alcohol consumption and smoking on blood pressure and on the achievement of blood pressure target values in treated hypertensive patients]. Orv Hetil. 2020; 161(30): 1252-1259.

(Beérkezett: 2020. február 23.; elfogadva: 2020. március 24.)

\begin{abstract}
Rövidítések
$\mathrm{ACE}=$ (angiotensin-converting enzyme) angiotenzinkonvertáló enzim; $\mathrm{BMI}=($ body mass index $)$ testtömegindex; $\mathrm{CI}=$ (confidence interval) megbízhatósági intervallum; $\mathrm{CV}=$ cardiovascularis; $\mathrm{DBP}=($ diastolic blood pressure $)$ diasztolés vérnyomás; ETT TUKEB = Egészségügyi Tudományos Tanács Tudományos és Kutatásetikai Bizottsága; GBD $=$ (global burden of disease) a betegség globális terhe; GLM = (general linear model) általános lineáris modell; MHR = Magyar Hypertonia Regiszter; SBP = (systolic blood pressure) szisztolés vérnyomás; $\mathrm{WHO}=$ (World Health Organization) Egészségügyi Világszervezet
\end{abstract}

A GBD Tobacco Collaborators munkacsoport 2017. évi elemzésében közlik 195 ország és WHO-régiók szerint a 1990 és 2015 közötti dohányzásprevalenciát és a dohányzással összefüggő „betegségterhet”. A dohányzók korra illesztett globális prevalenciája 2015-ben férfiaknál 25\% (24,2-28,7 95\% CI) volt. Az előfordulás 51 országban - elsősorban Közép- és Kelet-Európában, valamint Délkelet-Ázsiában - ennél magasabb volt. Nőknél a globális prevalencia 5,4\% (5,1-5,7 95\% CI) volt, ugyanakkor 70 országban, elsősorban Nyugat- és Közép-Európában nagyobb volt az előfordulás. A dohányzás az összhalálozás 3. legjelentősebb kockázati tényezője [1]. A GBD 2016 Alcohol Collaborators 2018-ban megjelent hasonló, világméretű felmérése szerint 2016-ban globálisan a rendszeres alkoholfogyasztók aránya a férfiaknál $32,5 \%$, a nőknél $25 \%$ volt, és a 7 . legjelentősebb halálozási kockázati tényező [2]. Hart és mtsai 30 évig tartó megfigyeléses vizsgálat alapján 35-64 éves egyénekben igazolták, hogy a két kockázati tényező együttes jelenléte szignifikáns mértékben növeli az összhalálozást, kétszeresére emeli a koszorúér-betegséggel, háromszorosára a stroke-kal összefüggő halálozást, ötszörösére a tüdőcarcinoma és 10-szeresére a krónikus légúti betegségek okozta halálozást, szemben azokkal, akik nem dohányoztak, és nem ittak rendszeresen alkoholt [3]. Ismereteink az alkohol és a dohányzás vérnyomásra gyakorolt hatásáról hypertoniás betegek esetében még hiányosak, bár az eddigi adatok alapján az alkohol esetében döntő a tartós rendszeres fogyasztás, amelynél a fogyasztás mér- tékének összefüggése a vérnyomás-emelkedéssel nők esetében J-görbe alakot mutat, míg férfiaknál az összefüggés inkább lineáris $[4,5]$. A dohányzás vérnyomásra gyakorolt hatását két szakaszra lehet bontani: az első, akut fázisban kissé csökkenti a vérnyomást, de a második, tartós fázisban a nikotin és a szén-monoxid toxikus hatása miatt az érfal merevebbé válik, és a szisztolés nyomás emelkedni kezd. Mindezek mögött eredendően a fokozott szimpatikus aktiváció, az angiotenzin-II-kiáramlás és ezek következményei állnak [6, 7]. Ezzel függ össze a minden esetben észlelhető emelkedett szívfrekvencia is [8]. Vizsgálatunk célja, hogy középkorú hypertoniás betegekben összehasonlítsuk a nem dohányzó és alkoholt nem rendszeresen fogyasztó személyek vérnyomásértékeit, a célvérnyomást elérők arányát és a szívfrekvenciát azokéval, akik rendszeresen dohányoznak és fogyasztanak alkoholt.

\section{Betegek és módszer}

A Magyar Hypertonia Regiszterbe (MHR) 2015-ben március 1. és május 31. között 27399 kezelt hypertoniás beteget vettünk fel. Közülük 12615 45-64 éves beteg (6341 férfi és 6274 nő) került a jelenlegi elemzésbe, akiknél önbevallás alapján regisztráltuk a dohányzás és az alkoholfogyasztás mértékét. A két kockázati tényező mértékét nem vizsgáltuk, így csak a rendszeresen dohányzókat ( $\geq$ napi 10 cigaretta) és alkoholt fogyasztókat (férfiaknál $\geq 28$ ital/hét, nőknél $\geq 7$ ital/hét) vettük figyelembe. A betegek kiválasztása a háziorvosi rendelőben történt folyamatosan, egymást követő napokon egy speciális Hypertonia Adatlap segítségével. A betegek átlagosan 3 havonta jelentkeztek háziorvosuknál ellenőrzésre. Minden beteg esetében reggeli rendelői vérnyomás- és pulzusszámmérés történt (két mérés átlagát vettük). Minden esetben megmértük az elhízás jellemzőit (BMI [testtömegindex], haskörfogat és szérumtriglicerid-szint), regisztráltuk a diabeteses betegeket. Az elemzés során 4 csoportot alakítottunk ki: I. csoport: nem dohányzó, alkoholt nem fogyasztó, II. csoport: csak dohányzó, III. csoport: csak rendszeres alkoholfogyasztó, IV. csoport: dohányzó és rendszeres alkoholfo- 
gyasztó. Az egyes csoportok közötti különbségeket vizsgáltuk a szisztolés (SBP) és a diasztolés (DBP) vérnyomásérték, a célvérnyomás, a nyugalmi pulzusszám, az antropológiai adatok, a trigliceridszint és a diabetes függvényében. A vérnyomásértékeket befolyásoló tényezőket többváltozós GLM- (general linear model) analízissel, a vérnyomáscélértéket el nem érés esélyét többváltozós logisztikus regresszióval elemeztük. Szignifikánsnak értékeltük a különbséget két változó között $\mathrm{p}<0,05$ esetén.

Az adatfelvételt az Egészségügyi Tudományos Tanács Tudományos és Kutatásetikai Bizottsága (ETT TUKEB) $21437 / 1 / 2015 /$ EKU (152/2015) ügyiratszámmal engedélyezte.

1. táblázat |45-64 éves hypertoniás férfiak alapadatai dohányzási és alkoholfogyasztási szokások szerint

\begin{tabular}{|c|c|c|c|c|c|}
\hline & & $\begin{array}{l}\text { I. } \\
\text { Dohány: nem } \\
\text { Alkohol: nem }\end{array}$ & $\begin{array}{c}\text { II. } \\
\text { Dohány: igen } \\
\text { Alkohol: nem }\end{array}$ & $\begin{array}{l}\text { III. } \\
\text { Dohány: nem } \\
\text { Alkohol: igen }\end{array}$ & $\begin{array}{l}\text { IV. } \\
\text { Dohány: igen } \\
\text { Alkohol: igen }\end{array}$ \\
\hline \multicolumn{2}{|l|}{ Esetszám, n (\%) } & $2737(43,2)$ & $1190(18,8)$ & $1018(16,1)$ & $1396(22,0)$ \\
\hline \multicolumn{2}{|c|}{ Kor, év (átlag \pm SD) } & $55,7 \pm 5,8$ & $55,5 \pm 5,8$ & $56,2 \pm 5,4$ & $55,8 \pm 5,5$ \\
\hline \multicolumn{2}{|c|}{$\mathrm{BMI}, \mathrm{kg} / \mathrm{m}^{2}$ (átlag $\left.\pm \mathrm{SD}\right)$} & $29,6 \pm 4,7$ & $29,1 \pm 4,6$ & $30,2 \pm 4,6$ & $29,7 \pm 4,8$ \\
\hline \multicolumn{2}{|c|}{ Haskörfogat, cm (átlag \pm SD) } & $100,1 \pm 14,6$ & $98,7 \pm 13,9$ & $102,7 \pm 13,9$ & $100,9 \pm 14,8$ \\
\hline \multicolumn{2}{|c|}{ Triglicerid, mmol/l (átlag \pm SD) } & $2,14 \pm 1,63$ & $2,28 \pm 2,05$ & $2,25 \pm 1,41$ & $2,33 \pm 1,78$ \\
\hline \multicolumn{2}{|l|}{ Diabetes, $\%$} & 25,1 & 23,7 & 27,8 & 31,8 \\
\hline \multicolumn{2}{|c|}{ Szisztolés vérnyomás, Hgmm (átlag \pm SD) } & $138,8 \pm 14,9$ & $140,5 \pm 15,4$ & $140,9 \pm 14,7$ & $144,7 \pm 16,3$ \\
\hline \multicolumn{2}{|c|}{ Diasztolés vérnyomás, Hgmm (átlag \pm SD) } & $82,3 \pm 8,0$ & $83,3 \pm 8,1$ & $83,6 \pm 8,1$ & $84,7 \pm 8,1$ \\
\hline \multicolumn{2}{|c|}{ Pulzusnyomás, Hgmm (átlag \pm SD) } & $56,5 \pm 12,9$ & $57,2 \pm 13,2$ & $57,3 \pm 12,8$ & $60,1 \pm 13,6$ \\
\hline \multicolumn{2}{|c|}{ Pulzusszám, ütés/perc (átlag \pm SD) } & $76,0 \pm 7,9$ & $77,1 \pm 8,0$ & $77,5 \pm 8,8$ & $78,3 \pm 8,6$ \\
\hline \multicolumn{2}{|c|}{ Vérnyomás<140/90 Hgmm, \% } & 46,6 & 43,2 & 42,3 & 31,1 \\
\hline \multicolumn{2}{|c|}{ Monoterápia aránya (\%) } & 14,3 & 9,9 & 12,7 & 8,0 \\
\hline \multirow{4}{*}{$\begin{array}{l}\text { A betegek } \\
\text { megoszlása a } \\
\text { hypertonia } \\
\text { kezelési tartama } \\
\text { szerint, \% }\end{array}$} & 1 éven belüli & 13,6 & 15,0 & 13,1 & 14,3 \\
\hline & 1-2 év & 13,8 & 14,5 & 11,3 & 12,5 \\
\hline & 3-5 év & 27,4 & 29,1 & 29,5 & 25,6 \\
\hline & $>5$ év & 45,2 & 41,4 & 46,1 & 47,6 \\
\hline
\end{tabular}

BMI = testtömegindex; SD = standard deviáció

2. táblázat |45-64 éves hypertoniás nők alapadatai, dohányzási és alkoholfogyasztási szokások szerint

\begin{tabular}{|c|c|c|c|c|c|}
\hline & & $\begin{array}{c}\text { I. } \\
\text { Dohány: nem } \\
\text { Alkohol: nem }\end{array}$ & $\begin{array}{c}\text { II. } \\
\text { Dohány: igen } \\
\text { Alkohol: nem }\end{array}$ & $\begin{array}{l}\text { III. } \\
\text { Dohány: nem } \\
\text { Alkohol: igen }\end{array}$ & $\begin{array}{l}\text { IV. } \\
\text { Dohány: igen } \\
\text { Alkohol: igen }\end{array}$ \\
\hline \multicolumn{2}{|l|}{ Esetszám, n (\%) } & $4184(66,7)$ & $1307(20,8)$ & $384(6,1)$ & $399(6,4)$ \\
\hline \multicolumn{2}{|c|}{ Kor, év (átlag \pm SD) } & $56,3 \pm 5,5$ & $55,3 \pm 5,6$ & $56,2 \pm 5,3$ & $55,4 \pm 5,6$ \\
\hline \multicolumn{2}{|c|}{$\mathrm{BMI}, \mathrm{kg} / \mathrm{m}^{2}($ átlag $\pm \mathrm{SD})$} & $29,1 \pm 5,7$ & $28,3 \pm 5,2$ & $29,5 \pm 5,2$ & $28,6 \pm 5,4$ \\
\hline \multicolumn{2}{|c|}{ Haskörfogat, cm (átlag \pm SD) } & $94,2 \pm 14,9$ & $93,1 \pm 14,4$ & $95,6 \pm 15,3$ & $93,7 \pm 13,9$ \\
\hline \multicolumn{2}{|c|}{ Triglicerid, mmol/1 (átlag \pm SD) } & $1,98 \pm 1,19$ & $1,99 \pm 1,03$ & $2,03 \pm 1,27$ & $2,18 \pm 1,15$ \\
\hline \multicolumn{2}{|l|}{ Diabetes, \% } & 20,4 & 21,7 & 17,7 & 28,8 \\
\hline \multicolumn{2}{|c|}{ Szisztolés vérnyomás, Hgmm (átlag \pm SD) } & $138,2 \pm 15,0$ & $138,9 \pm 16,9$ & $139,9 \pm 16,9$ & $141,9 \pm 16,8$ \\
\hline \multicolumn{2}{|c|}{ Diasztolés vérnyomás, Hgmm (átlag \pm SD) } & $81,9 \pm 8,1$ & $82,7 \pm 8,4$ & $82,6 \pm 8,8$ & $82,7 \pm 8,3$ \\
\hline \multicolumn{2}{|c|}{ Pulzusnyomás, Hgmm (átlag \pm SD) } & $56,2 \pm 12,7$ & $56,2 \pm 12,2$ & $57,3 \pm 13,9$ & $59,2 \pm 14,6$ \\
\hline \multicolumn{2}{|c|}{ Pulzusszám, ütés/perc (átlag \pm SD) } & $76,2 \pm 8,0$ & $76,9 \pm 8,6$ & $77,3 \pm 8,9$ & $78,1 \pm 9,3$ \\
\hline \multicolumn{2}{|c|}{ Vérnyomás<140/90 Hgmm, \% } & 49,8 & 47,4 & 45,6 & 41,1 \\
\hline \multicolumn{2}{|c|}{ Monoterápia aránya (\%) } & 15,1 & 10,8 & 13,0 & 9,3 \\
\hline \multirow{4}{*}{$\begin{array}{l}\text { A betegek } \\
\text { megoszlása a } \\
\text { hypertonia } \\
\text { kezelési tartama } \\
\text { szerint, \% }\end{array}$} & 1 éven belüli & 15,0 & 16,7 & 19,6 & 15,2 \\
\hline & 1-2 év & 12,5 & 13,0 & 12,3 & 15,9 \\
\hline & 3-5 év & 28,3 & 30,9 & 35,4 & 29,3 \\
\hline & $>5$ év & 44,2 & 39,4 & 32,7 & 39,6 \\
\hline
\end{tabular}

BMI = testtömegindex; SD = standard deviáció 

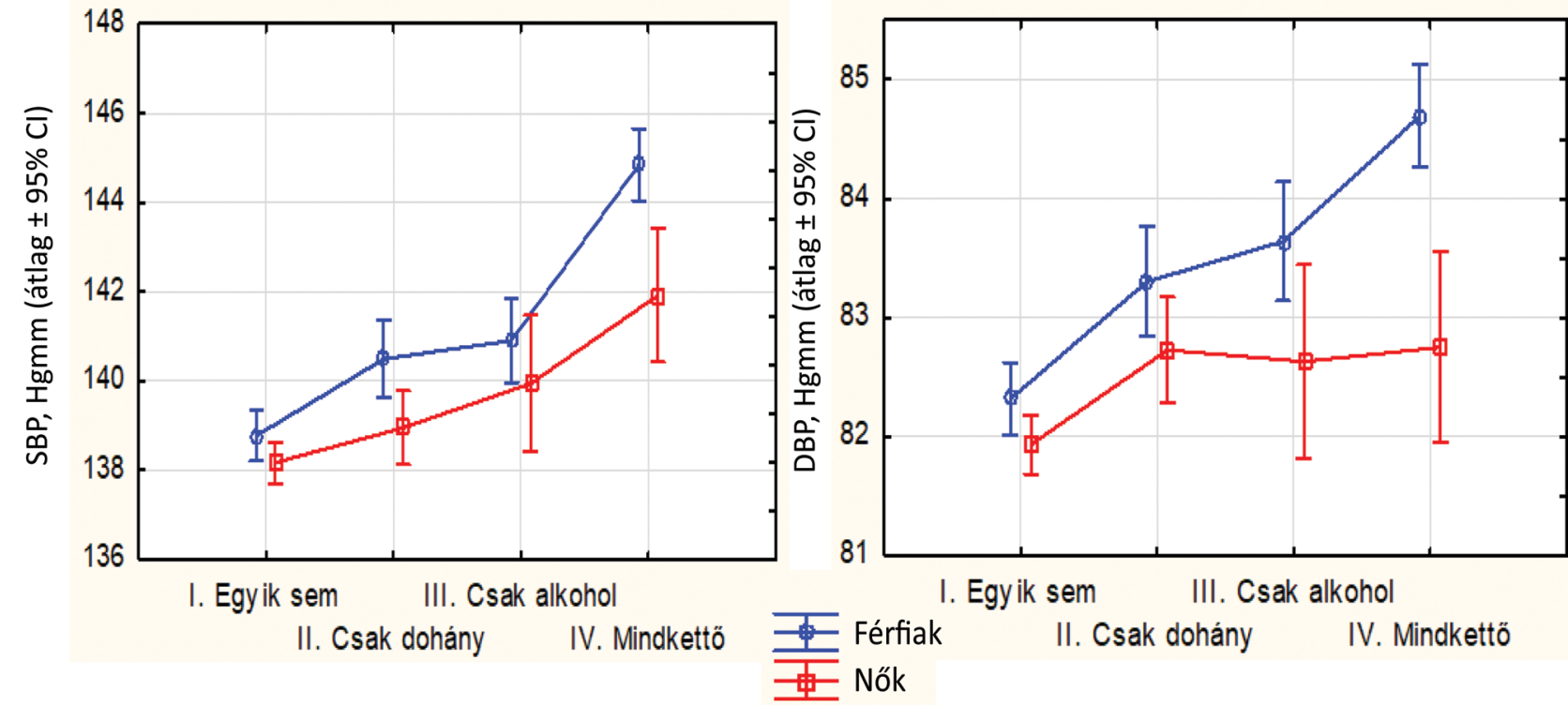

1. ábra

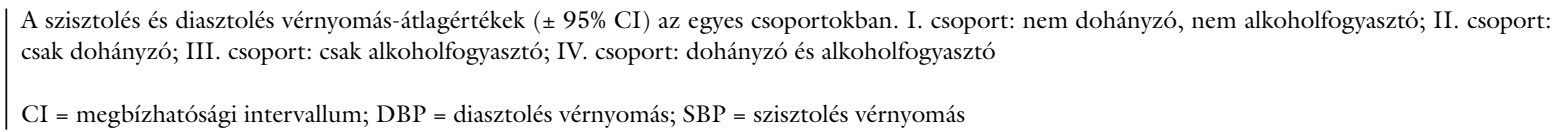

\section{Eredmények}

Az átlagéletkor a férfiak esetében $55,8 \pm 5,7$ év, a nók esetében $56,1 \pm 5,5$ év volt. A férfiak $40,8 \%$-a, a nők $27,2 \%$-a rendszeresen dohányzott. A rendszeres alkoholfogyasztók aránya férfiaknál 38,1\%, nóknél $12,5 \%$ volt. Mindkét nem esetén a betegek több mint kétharmada 3 évnél régebb óta részesült vérnyomáscsökkentő kezelésben. A betegek döntő többsége többszörös vérnyomáscsökkentő terápiában részesült, a monoterápia aránya mindkét nemnél, mindegyik csoport esetén $15 \%$ alatt volt. A regiszterben szereplő 45-64 éves férfiak és nők jellemzố alapadatait a négy vizsgált csoportban az 1 . és 2. táblázat tartalmazza.

A szisztolés és diasztolés vérnyomás értékei közötti különbséget az egyes csoportokban az 1 . ábrán és a 3. táblázatban mutatjuk be.

Férfiaknál minden csoportban nagyobbak $(\mathrm{p}<0,001)$ a vérnyomás-átlagértékek, mint nőknél. A szisztolés és diasztolés vérnyomás-átlagértékek mindkét nem esetén szignifikánsan magasabbak $(\mathrm{p}<0,001)$ voltak azon hypertoniásoknál, akik rendszeresen dohányoznak és fogyasz- tanak alkoholt, azokhoz képest, akik nem dohányoznak és nem fogyasztanak rendszeresen alkoholt. Férfiaknál a szisztolés és a diasztolés vérnyomás átlagértéke azok körében is nagyobb, akik csak dohányoznak, vagy csak alkoholt fogyasztanak; nók esetében ez nem igazolható.

A szisztolés és a diasztolés vérnyomást befolyásoló tényezők elemzését többváltozós GLM-analízissel a 4. táblázat mutatja.

A rendszeres dohányzás és az alkoholfogyasztás férfiaknál és nóknél erősen befolyásolja a szisztolés vérnyomás értékét, ugyanakkor a diasztolés érték esetében ez csak a férfiaknál érvényesül. A BMI és a trigliceridszint szignifikáns befolyásoló tényező mindkét nem esetén. A diabetes jelenléte nóknél szignifikáns tényező.

Önmagában a BMI, a haskörfogat és a szérumtriglicerid vonatkozásában a négy csoport között szignifikáns különbséget nem találtunk.

Az egyes csoportokban a diabetes gyakoriságát a 2. ábrán mutatjuk be. Férfiak esetében a rendszeres alkoholfogyasztók és dohányosok körében nagyobb $(\mathrm{p}<0,001)$ a diabetes előfordulása $(31,8 \%)$ azokhoz képest, akik nem

3. táblázat |A vérnyomásértékek közötti különbségek szignifikanciája csoportok szerint. I. csoport: nem dohányzó, nem alkoholfogyasztó; II. csoport: csak dohányzó; III. csoport: csak alkoholfogyasztó; IV. csoport: dohányzó és alkoholfogyasztó

\begin{tabular}{|c|c|c|c|c|c|c|}
\hline Szisztolés vérnyomás & I. vs. II. & I. vs. III. & I. vs. IV. & II. vs. III. & II. vs. IV. & III. vs. IV. \\
\hline Férfiak, p-érték & $<0,01$ & $<0,001$ & $<0,001$ & 0,92 & $<0,001$ & $<0,001$ \\
\hline Nők, p-érték & 0,38 & 0,1 & $<0,001$ & 0,68 & $<0,01$ & 0,27 \\
\hline Diasztolés vérnyomás & I. vs. II. & I. vs. III. & I. vs. IV. & II. vs. III. & II. vs. IV. & III. vs. IV. \\
\hline Férfiak, p-érték & $<0,01$ & $<0,001$ & $<0,001$ & 0,76 & $<0,001$ & $<0,01$ \\
\hline Nők, p-érték & 0,013 & 0,38 & 0,23 & 0,99 & 0,99 & 0,99 \\
\hline
\end{tabular}


4. táblázat |A vérnyomásértékeket meghatározó tényezők elemzése

\begin{tabular}{|c|c|c|c|c|}
\hline \multirow[t]{2}{*}{ Befolyásoló tényezôk } & \multicolumn{2}{|c|}{$\begin{array}{c}\text { Szisztolés vérnyomás, } \\
\text { p-érték }\end{array}$} & \multicolumn{2}{|c|}{$\begin{array}{c}\text { Diasztolés vérnyomás, } \\
\text { p-érték }\end{array}$} \\
\hline & Férfiak & Nők & Férfiak & Nők \\
\hline Életkor (45-64 év) & 0,012 & $<0,01$ & $<0,01$ & $<0,001$ \\
\hline Dohányzás & $<0,001$ & $<0,001$ & $<0,001$ & 0,13 \\
\hline Alkoholfogyasztás & $<0,001$ & $<0,01$ & $<0,001$ & 0,47 \\
\hline Diabetes mellitus & 0,07 & $<0,001$ & 0,046 & $<0,01$ \\
\hline BMI & $<0,001$ & $<0,001$ & $<0,001$ & $<0,001$ \\
\hline Triglicerid & $<0,001$ & $<0,001$ & $<0,001$ & $<0,001$ \\
\hline
\end{tabular}

$\mathrm{BMI}=$ testtömegindex

dohányoznak és nem fogyasztanak rendszeresen alkoholt $(25,1 \%)$. Ez az arány nók esetében is szignifikáns különbséget mutat $(28,8 \%$ szemben a $20,4 \%$-kal, $\mathrm{p}<0,001)$. Férfiaknál mind a négy csoportban magasabb előfordulási értékeket kaptunk $(\mathrm{p}<0,001)$.

A négy vizsgált csoportban a célvérnyomás (<140/90 Hgmm) elérési arányában a dohányzási és az alkoholfogyasztási szokások szerint lényeges különbségek állnak fenn. A különbségeket és azok mértékét a 3. ábrán mutatjuk be.

A nök esetében minden csoportban nagyobb $(\mathrm{p}<0,001)$ volt a célvérnyomást elérők aránya. A rendszeresen dohányzó és alkoholt fogyasztó betegek esetében kisebb a célvérnyomást elérők aránya, mint azok körében, akik nem fogyasztanak rendszeresen alkoholt és nem dohányoznak. Az arány férfiaknál 31,1\% a 46,6\%kal szemben ( $\mathrm{p}<0,001)$, nőknél 41,1\% a 49,8\%-kal szemben $(p<0,01)$. Férfiaknál különösen alacsony a rendsze-

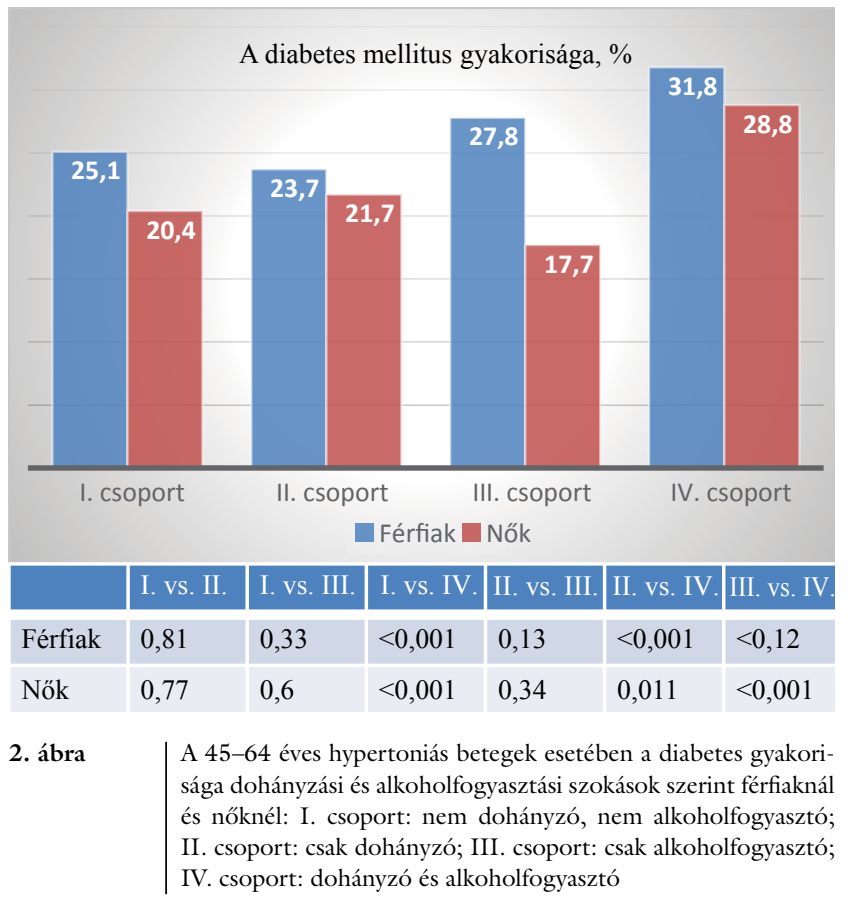

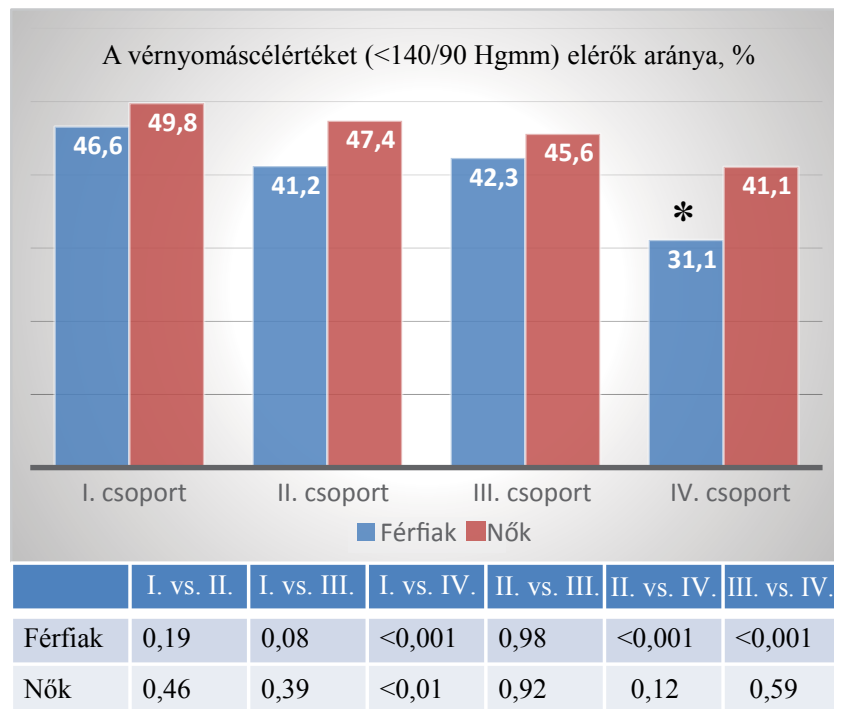

3. ábra $\quad$ A $140 / 90 \mathrm{Hgmm}$ alatti célvérnyomást elérők aránya százalékban dohányzási és alkoholfogyasztási szokások szerint 45-64 éves férfiak és nók esetében. I. csoport: nem dohányzó, nem alkoholfogyasztó; II. csoport: csak dohányzó; III. csoport: csak alkoholfogyasztó; IV. csoport: dohányzó és alkoholfogyasztó

*Férfiak vs. nók $\mathrm{p}<0,001$

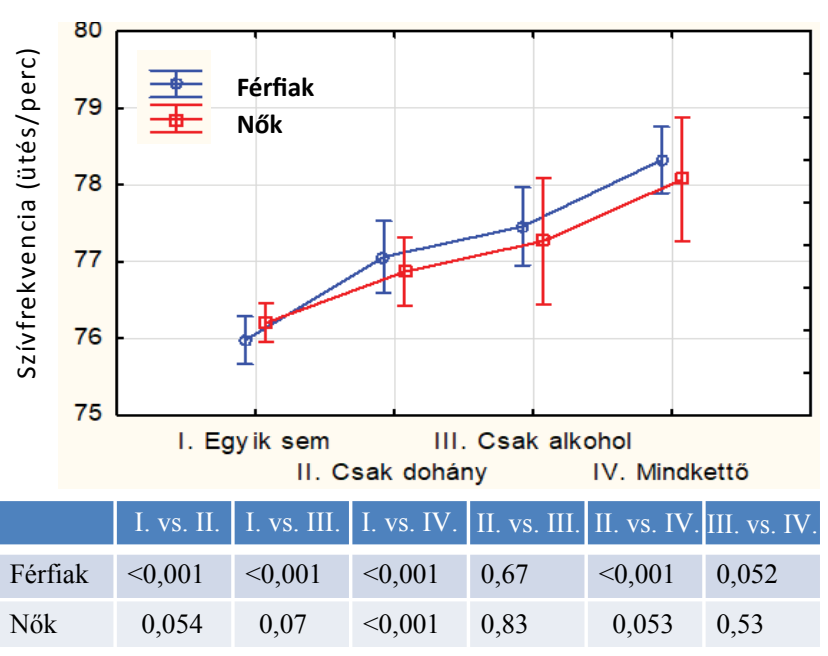

4. ábra

A szívfrekvencia-átlagértékek ( \pm 95\%-os CI) az egyes csoportok ban. I. csoport: nem dohányzó, nem alkoholfogyasztó; II. csoport: csak dohányzó; III. csoport: csak alkoholfogyasztó; IV. csoport: dohányzó és alkoholfogyasztó

$\mathrm{CI}$ = megbízhatósági intervallum

resen dohányzó és alkoholizáló betegcsoportban a célértéket elérők aránya $(31,1 \%)$.

A célvérnyomás el nem érésének esélyét többváltozós logisztikus regresszióval is elemeztük (5. táblázat). Az elemzés arra utal, hogy a célvérnyomás elérésének mértékét egyértelmúen a két kockázati tényező együttes jelenléte, valamint az elhízás (BMI>30 kg/m²), a kóros szérumtriglicerid és a diabetes mellitus fennállása befolyásolja.

A 45-64 év közötti életkorú hypertoniás betegek szívfrekvencia-átlagait az egyes csoportokban a 4. ábra mu- 
5. táblázat |A célvérnyomás (<140/90 Hgmm) el nem érési esélyének tényezői korhoz illesztett többváltozós logisztikus regresszióval

\begin{tabular}{lccc|cccc}
\hline Befolyásoló tényezök & \multicolumn{5}{c}{ Többváltozós logisztikus regresszió (korra illesztett) } \\
\cline { 2 - 8 } & \multicolumn{3}{c}{ Férfiak } & \multicolumn{3}{c}{ Nók } \\
\cline { 2 - 8 } & OR & $95 \% \mathrm{CI}$ & $\mathrm{p}$ & $\mathrm{OR}$ & $95 \%$ CI & $\mathrm{p}$ \\
\hline Csak dohányzás vs. egyik sem & 1,18 & $1,02-1,36$ & 0,02 & 1,06 & $0,93-1,21$ & 0,38 \\
\hline Csak alkoholfogyasztás vs. egyik sem & 1,13 & $0,97-1,31$ & 0,12 & 1,09 & $0,88-1,36$ & 0,44 \\
\hline Dohányzás és alkoholfogyasztás vs. egyik sem & 1,82 & $1,59-2,10$ & $<0,001$ & 1,37 & $1,10-1,71$ & $<0,01$ \\
\hline BMI $\geq 30 \mathrm{~kg} / \mathrm{m}^{2}$ & 1,39 & $1,25-1,55$ & $<0,001$ & 1,43 & $1,28-1,59$ & $<0,001$ \\
\hline Triglicerid $\geq 1,7$ mmol/1 & 1,59 & $1,42-1,77$ & $<0,001$ & 1,54 & $1,38-1,71$ & $<0,001$ \\
\hline Diabetes & 1,18 & $1,04-1,33$ & $<0,01$ & 1,28 & $1,13-1,46$ & $<0,001$ \\
\hline
\end{tabular}

$\mathrm{BMI}=$ testtömegindex; CI = megbízhatósági intervallum; OR = esélyhányados

tatja. A szívfrekvencia átlaga nagyobb a csak dohányzók vagy rendszeres alkoholfogyasztók esetében azokkal szemben, akiknél egyik abúzus sem áll fenn. Egyértelmú és mindkét nemben egyaránt megfigyelhető a különbség $(\mathrm{p}<0,001)$ a nem dohányzó és alkoholt nem fogyasztó, valamint a rendszeresen dohányzó és alkoholfogyasztó csoportok között.

\section{Megbeszélés}

Az alkohol és a dohányzás cardiovascularis $(\mathrm{CV})$ hatásait számos elemzés és vizsgálat bemutatta korábban. A legtöbb elemzés a kérdést szétbontva tárgyalja. Az alkohol vonatkozásában már a HARVEST-tanulmány igazolta, hogy hypertoniás betegekben a vérnyomásra gyakorolt hatásánál lényeges különbség áll fenn a nem ivók, a mérsékelt és a rendszeresen nagy mennyiségű alkoholt fogyasztók között [9]. Az utóbbiaknál a 24 órás és a nappali SBP szignifikánsan nagyobb volt, mint a nem ivók esetében, és ez náluk nagyobb bal kamrai izomtömeggel is társult [9]. Holmes és mtsai 2014-ben 261991 európai egyénnél mendeli randomizációs metaanalízissel részletesen elemezték az alkohol CV hatásait [10]. Egyértelmûen tisztázódott, hogy a kismértékű alkoholfogyasztás kedvező, a rendszeres és nagy mennyiségü alkoholfogyasztás megnöveli a CV kockázatot. A rendszeres, nagy mennyiségú alkoholfogyasztás normotoniás és hypertoniás egyéneknél egyaránt megemeli a vérnyomást, nő a vérnyomás-variabilitás, és normotoniásoknál elősegíti a hypertonia kialakulását. Különösen károsnak tartják a rendszeres ivóknál a beiktatott nagy „ivászatokat” a vérnyomás szempontjából [10-13]. Valójában egy U-görbéhez hasonlítják az alkoholfogyasztás és hypertonia kapcsolatát, illetve CV következményeit, melynek két emelkedő szára az absztinensek, illetve a "nagyivók” [10]. Mindezen elváltozások természetesen függetlenek az alkoholfogyasztáskor fellépő kétfázisú vérnyomásváltozástól (emelkedés, majd esés) [14].

A dohányzás akut hatása tekintetében Groppelli és mtsai már 1992-ben leírták, hogy normotoniás egyének- ben nagy mennyiségű cigaretta elszívása tartósan megemeli a szisztolés és a diasztolés vérnyomást, valamint a szívfrekvenciát [15]. Ezen időszakban számos vizsgálat erősítette azt a véleményt, hogy a rendszeresen dohányzóknál a vérnyomás csökken normotoniás és hypertoniás egyénekben egyaránt $[16,17]$. A későbbiekben ez a nézet annyira megerősödött, hogy a dohányzást nem tartották a hypertonia rizikófaktorának [18]. Leone tisztázta a dohányzás és a hypertonia kapcsolatát. Vizsgálatai szerint a tartós és rendszeres dohányzás két fázisban hat a vérnyomásra: az első időszakban szignifikánsan esik a szisztolés és a diasztolés vérnyomás, és ez mindkét nemben és életkortól függetlenül érvényesül. Azonban már ebben az időszakban is érvényesül a nikotin által kiváltott fokozott szimpatikus aktivitás, endothelialis diszfunkció, de - feltehetően az endothelből kiáramló nitrogén-monoxid hatására - inkább kismértékű vérnyomásesés jön létre. A nikotin és különösen a szén-monoxid érfalkárosító hatása folyamatosan érvényesül, nő az artériás 'stiffness' (az artériák rugalmatlanná válása), romlik a thrombocytafunkció, így a második fázisban tartósan megemelkedik a vérnyomás, majd kialakul a hypertoniás szívbetegség [6, 7]. A dohányzás hatását Leone Pandóra szelencéjéhez hasonlította [7]. Obta és mtsai 2016-ban közölték, hogy középkorú, kezelt hypertoniás betegekben a dohányzó időszakban mért átlagos 24 órás és nappali vérnyomás, valamint szívfrekvencia nagyobb volt, mint a nem dohányzó időszakban, sőt a vérnyomás-variabilitás is jelentősebb volt ebben az időszakban a nem dohányzó periódushoz képest [19]. Hazánkban Kékes a 2005. évi Hypertonia Regiszter adatbázisa alapján, kezelt hypertoniásoknál az emelkedő szisztolés és diasztolés vérnyomással párhuzamosan egyre nagyobbnak találta a dohányzók arányát [20].

Kevesebb tanulmány van a témáról, és kevésbé ismert, hogy a rendszeres alkoholfogyasztás és dohányzás együttes hatása megduplázza, megháromszorozza a CV események (coronariabetegség, stroke és perifériás verőérbetegség) előfordulását $[3,21]$. Ez kiemelten jelentős hypertoniás betegek esetében, különösen, ha már balkamra-hypertrophia is fennáll $[9,21]$. Az alkohol fokoz- 
za a dohányzás során érvényesülő káros nikotin és szénmonoxid hatását. Fokozott szimpatikus aktivitás, katecholamin-kiáramlás, oxidatív stressz, endotheldiszfunkció károsítja az ereket és szöveteket [21, 22]. $\mathrm{Az}$ együttes hatás társadalmi szempontból is jelentős, mert ismert, hogy az alkoholfogyasztók jelentős része erósen dohányzik [22].

Saját vizsgálatunkban egyértelmúen igazolni tudtuk, hogy a rendszeres alkoholfogyasztó és dohányzó betegek vérnyomása és pulzusszáma magasabb azokkal szemben, akik rendszeresen nem fogyasztanak alkoholt és nem dohányoznak. Férfiaknál a szisztolés és diasztolés vérnyomás átlagértéke azok körében is nagyobb, akik csak dohányoznak, vagy csak alkoholt fogyasztanak; nőknél ezt nem észleltük. Többváltozós lineáris modellezéssel igazoltuk, hogy a rendszeres dohányzás és az alkoholfogyasztás férfiaknál és nőknél erősen befolyásolja a szisztolés vérnyomás értékét, a diasztolés érték vonatkozásában ez csak a férfiaknál érvényesül. Az elhízás (BMI és a trigliceridszint) mindkét nemnél, a diabetes a nők esetében ugyancsak szignifikáns befolyásoló tényező.

Kiemelten fontosnak tartjuk, hogy a kezelt hypertoniás betegek esetében az együttes dohányzás és alkoholfogyasztás igen kedvezőtlenül befolyásolta a célvérnyomás (<140/90 Hgmm) elérésének esélyét. Erős befolyásoló tényező a két rizikófaktor együttes jelenléte, valamint az elhízás és a diabetes is.

A fentiekben ismertetett hatásokon túl még fontos szerepe lehet a nikotin és az egyes antihipertenzív szerek között fennálló kölcsönhatásnak is [7, 23]. A hagyományos béta-blokkolók a nikotin okozta fokozott szimpatikus aktivitást és a csökkent paraszimpatikus aktivitást nehezen törik át, kivétel a 3. generációs nebivolol, valamint a karvedilol [7, 24]. A rendszeres dohányzás erősen befolyásolja az ACE-inhibitorok hatását kezelt hypertoniásoknál, különösen diabeteses nephropathiában [25]. Ennek fó oka, hogy a nikotin fokozza a reninkiáramlást, valamint az angiotenzin-I $\rightarrow$ angiotenzin-II átalakulást az ACE serkentése révén [26]. A nikotin antidiuretikus hatása befolyásolja a tiazidok hatását dohányzó hypertoniásoknál $[7,24]$. Indapamiddal kezelt dohányos hypertoniások esetében nem találtak eltérést az antihipertenzív hatásban [27]. Az alkohol vonatkozásában elsősorban a nagy alkoholfogyasztók esetében kialakuló erős szimpatikus aktivitás és angiotenzin-II-szint-emelkedés játszhat szerepet a nem kielégítő célvérnyomás elérésében [28]. A kalciumantagonista szerek hatását egyik rizikótényező sem befolyásolja.

Vizsgálatunk korlátját jelenti, hogy a rögzített dohányzási és alkoholfogyasztási szokások önbevalláson alapultak. Mivel azonban e módszer ismerten „lefelé” torzítja a káros szenvedélyek használatának mértékét, az eredmények még markánsabban jelentkeztek volna, ha rendelkezésünkre áll objektív mennyiségi mérés lehetősége. Ugyancsak korlátozó tényező, hogy nem áll rendelkezésünkre adat a gyógyszeres kezelés adherenciájáról. A rendszeres alkoholfogyasztók terápiás együttmú- ködése valószínúsíthetően elmarad az alkoholt nem fogyasztókétól, és ez a tény részben magyarázhatja a kapott eredményeket. Nem ismeretes a fizikailag aktív betegek aránya, ami szintén befolyásolhatja a kapott eredményeket. Végül, de nem utolsósorban természetesen nehezíti a csoportok összehasonlíthatóságát az a tény, hogy a vizsgált négy csoportban a betegek nem azonos terápiában részesültek.

\section{Következtetés}

Vizsgálatunk alapján a rendszeres alkoholfogyasztás és dohányzás rontja a célvérnyomás elérésének esélyét középkorú, kezelt hypertoniás személyekben. A jelenség pontos okának megértéséhez további prospektív vizsgálatok szükségesek.

Anyagi támogatás: Az adatfelvétel 2015-ben, az EGIS Gyógyszergyár Zrt. Magyar Hypertonia Társaságnak nyújtott támogatásával történt. A 2019. évben végzett adatfeldolgozás során a szerzők anyagi támogatásban nem részesültek.

Szerzői munkamegosztás: K. E. és J. Z. az adatfeldolgozásban és a kézirat megszövegezésében, P. A. a statisztikai elemzésben, B.-B. V. és Sz. V. B. az adatfeldolgozásban és a kézirat kritikai véleményezésében vett részt. A közlemény végleges változatát valamennyi szerző elolvasta és jóváhagyta.

Érdekeltségek: A szerzőknek nincsenek érdekeltségeik.

\section{Köszönetnyilvánítás}

A szerzők köszönetet mondanak az EGIS Gyógyszergyár Zrt. és a Magyar Hypertonia Társaság támogatásáért és a vizsgálatban részt vevő háziorvos kollégák adatszolgáltatásáért.

\section{Irodalom}

[1] GBD 2015 Tobacco Collaborators. Smoking prevalence and attributable disease burden in 195 countries and territories, 19902015: a systematic analysis from the Global Burden of Disease Study 2015. Lancet 2017; 389: 1885-1906. [Correction: Lancet 2017; 390: 1644.]

[2] GBD 2016 Alcohol Collaborators. Alcohol use and burden for 195 countries and territories, 1990-2016: a systematic analysis for the Global Burden of Disease Study 2016. Lancet 2018; 392: 1015-1035. [Correction: Lancet 2018; 392: 1116.]

[3] Hart CL, Davey Smith G, Gruer L, et al. The combined effect of smoking tobacco and drinking alcohol on cause-specific mortality: a 30-year cohort study. BMC Public Health 2010; 10: 789.

[4] Piano MR. Alcohol's effects on the cardiovascular system. Alcohol Res. 2017; 38: 219-241.

[5] Briasoulis A, Agarwal V, Messerli FH. Alcohol consumption and the risk of hypertension in men and women: a systematic review and meta-analysis. J Clin Hypertens (Greenwich). 2012; 14: $792-798$.

[6] Leone A. Smoking and hypertension. J Cardiol Curr Res. 2015; 2: 00057. Doi: 10.15406/jecr.2015.02.00057. 
[7] Leone A. Does smoking act as a friend or enemy of blood pressure? Let release Pandora's box. Cardiol Res Pract. 2011; 2011 264894. Doi:10.4061/2011/264894.

[8] Linneberg A, Jacobsen RK, Skaaby T, et al. Effect of smoking on blood pressure and resting heart rate: a Mendelian randomisation meta-analysis in the CARTA consortium. Circ Cardiovasc Genet. 2015; 8: 832-841.

[9] Vriz O, Piccolo D, Cozzutti E, et al. The effects of alcohol consumption on ambulatory blood pressure and target organs in subjects with borderline to mild hypertension. HARVEST Study Group. Am J Hypertens. 1998; 11: 230-234.

[10] Holmes MV, Dale CE, Zuccolo L, et al. Association between alcohol and cardiovascular disease: Mendelian randomisation analysis based on individual participant data. BMJ 2014; 349: g4164. Doi: $10.1136 /$ bmj.g4164.

[11] Rehm J, Gmel GE Sr, Gmel G, et al. The relationship between different dimensions of alcohol use and the burden of disease an update. Addiction 2017; 112: 968-1001.

[12] Miller PM, Anton RF, Egan BM, et al. Excessive alcohol consumption and hypertension: clinical implications of current research. J Clin Hypertens (Greenwich). 2005; 7: 346-351.

[13] Santana NM, Mill JG, Velasquez-Melendez G, et al. Consumption of alcohol and blood pressure: results of the ELSA-Brasil study. PLoS ONE 2018; 13: e0190239.

[14] Adesso VJ, Ritchie SA, Stasiewicz PR. The acute effects of alcohol on the blood pressure of young, normotensive men. J Stud Alcohol. 1990; 51: 468-471.

[15] Groppelli A, Giorgi DM, Omboni S, et al. Persistent blood pressure increase induced by heavy smoking. J Hypertens. 1992; 10: 495-499.

[16] Hughes K, Leong WP, Sothy SP, et al. Relationships between cigarette smoking, blood pressure and serum lipids in the Singapore general population. Int J Epidemiol. 1993; 22: 637-643.

[17] Ballantyne D, Devine BL, Fife R. Interrelation of age, obesity, cigarette smoking, and blood pressure in hypertensive patients. Br Med J. 1978; 1(6117): 880-881.

[18] Li G, Wang H, Wang K, et al. The association between smoking and blood pressure in men: a cross-sectional study. BMC Public Health 2017; 17: 797.
[19] Ohta Y, Kawano Y, Hayashi S, et al. Effects of cigarette smoking on ambulatory blood pressure, heart rate, and heart rate variability in treated hypertensive patients. Clin Exp Hypertens. 2016; 38: 510-513.

[20] Kékes E. Cardiovascular risk of smoking, hypertensive patients. Therapeutic options. [A dohányzó hipertóniás betegek kardiovaszkuláris rizikója. Terápiás lehetőségek.] Háziorv Továbbk Szle. 2006; 11: 924-928. [Hungarian]

[21] Palatini P, Fania C, Mos L, et al. Alcohol intake more than doubles the risk of early cardiovascular events in young hypertensive smokers. Am J Med. 2017; 130: 967-974.

[22] Adams S. Psychopharmacology of tobacco and alcohol comorbidity: a review of current evidence. Curr Addict Rep. 2017; 4: $25-34$.

[23] Kékes E, Kiss I. Smoking and the effect of antihypertensive agents. [A dohányzás és az antihipertenzív szerek hatása.] Hyperton Nephrol. 2015; 19: 215-217. [Hungarian]

[24] Cohen DL, Townsend RR. Does cigarette use modify blood pressure measurement or the effectiveness of blood pressure medications? J Clin Hypertens. 2009; 11: 657-658.

[25] Scott LJ, Warram JH, Hanna LS, et al. A nonlinear effect of hyperglycemia and current cigarette smoking are major determinants of the onset of microalbuminuria in type 1 diabetes. Diabetes 2001; 50: 2842-2849.

[26] Oakes JM, Fuchs RM, Gardner JD, et al. Nicotine and the reninangiotensin system. Am J Physiol Regul Integr Comp Physiol. 2018; 315: R895-R906.

[27] Kobalava ZD, Kotovskaya YV, Moiseev VS. Efficacy and acceptability of indapamide sustained release in elderly high-risk hypertensive patients: the ARGUS study. High Blood Press Cardiovasc Prev. 2008; 15: 275-282.

[28] Husain K, Ansari RA, Ferder L. Alcohol-induced hypertension: mechanism and prevention. World J Cardiol. 2014; 6: 245-252.

(Járai Zoltán dr., Budapest, Tétényi út 12-16., 1115 e-mail: kardiologia@szentimrekorhaz.hu)

\section{A rendezvények és kongresszusok híranyagának leadása}

a lap megjelenése elött legalább 40 nappal lehetséges, a 6 hetes nyomdai átfutás miatt. Kérjük megrendelőink szíves megértését.

A híranyagokat a következő címre kérjük:

Orvosi Hetilap titkársága: edit.budai@akademiai.hu

Akadémiai Kiadó Zrt.

A cikk a Creative Commons Attribution 4.0 International License (https://creativecommons.org/licenses/by/4.0/) feltételei szerint publikált Open Access közlemény, melynek szellemében a cikk bármilyen médiumban szabadon felhasználható, megosztható és újraközölhető, feltéve, hogy az eredeti szerző és a közlés helye, illetve a CC License linkje és az esetlegesen végrehajtott módosítások feltüntetésre kerülnek. (SID_1) 